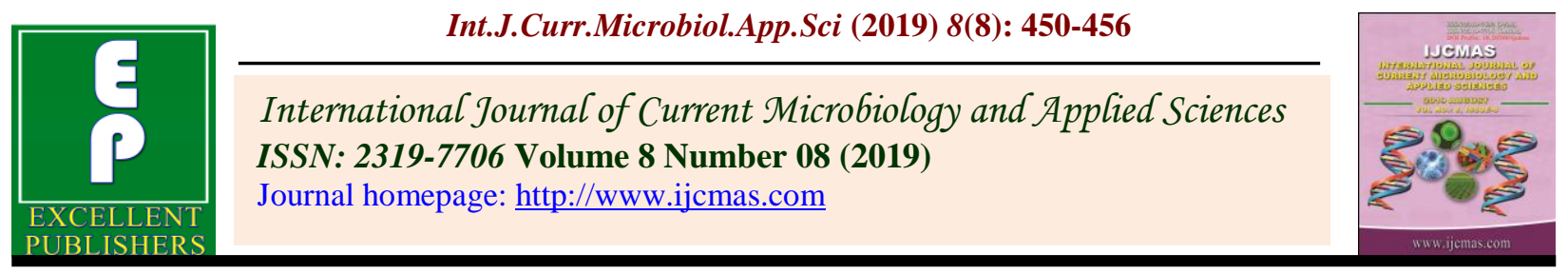

Original Research Article

https://doi.org/10.20546/ijcmas.2019.808.051

\title{
In vitro Evaluation of Systemic, Non-Systemic and Combi Fungicides against Colletotrichum gloeosporoides Causing Fungal Fruit Rot in Pomegranate
}

\author{
K.A. Burgute* and S.J. Magar \\ Department of Plant Pathology, College of Agriculture, Latur, Vasantrao Naik Marathwada \\ Krishi Vidyapeeth, Parbhani (M.S.) India \\ *Corresponding author
}

\begin{tabular}{|l|}
\hline Ke y w or d s \\
Colletotrichum \\
gloeosporoides, \\
Fungicides, Fungal, \\
Fruit rot, \\
Pomegranate \\
\hline Article Info \\
\hline $\begin{array}{l}\text { Accepted: } \\
\text { 07 July 2019 } \\
\text { Available Online: } \\
\text { 10 August } 2019\end{array}$ \\
\hline \hline
\end{tabular}

A B S T R A C T

In vitro evaluation of systemic, non-systemic and combi fungicides against Colletotrichum gloeosporoides causing fungal fruit rot in pomegranate were carried out in the Department of Plant Pathology, College of Agriculture, Latur during the year 2017-18. Among the systemic fungicides at $1000 \mathrm{ppm}$ concentration Carbendazim 50 WP showed (87.23\%) inhibition of mycelial growth of fungus followed by Difenconazole $25 \mathrm{EC}$ with $(85.74 \%)$ and least inhibition of mycelial growth was recorded in Propiconazole 25 EC (74.66\%). The non-systemic and combi fungicides were evaluated against the pathogen at 2000 ppm concentration. Among the non-systemic and combi fungicides the maximum percent inhibition of growth of Colletotrichum gloeosporoides was observed in combi fungicides Carboxin 37.5 + Thirum 37.5 75 WP (95.62\%) followed by Caebendazim 12\% + Mancozeb 63\% 75 WP (94.00\%) and non-systemic fungicides Propineb 70 WP (51.48\%) followed by Chlorothalonil 75 WP (48.14). The least per cent inhibition of fungus was recorded in combi fungicides Cymoxanil 8\% + Mancozeb 64\%72 WP (19.13\%) and non-systemic fungicides Mancozeb 75 WP (42.77\%).

\section{Introduction}

Pomegranate (L.) is an important fruit crop of arid and semiarid regions of the World. India is one of the leading producers of pomegranate in the World. Maharashtra is the leading producer of pomegranate in India followed by Karnataka, Gujarat and Andhra Pradesh (Anonymous, 2013). Pomegranate is regarded as the "Fruit of Paradise". The most popular varieties in India are Ganesh, Mridula, Arakta, Bhagwa (Kesar). Successful cultivation of pomegranate in recent years has met with different problems such as pests and diseases. Among the various fungal diseases, fruit rot disease majorly caused Colletotrichum gloeosporoides (Penz.) Penz. and Sacc., is one of the most serious disease of pomegranate, remaining latent in early stages of fruit development, internal rotting and 
reducing fruit quality to a greater extent. The pathogen $C$. gloeosporoides responsible for fruit rot was first reported in India by Butler (1918). Fungal fruit rot of pomegranate caused by Colletotrichum gloeosporoides (Penz.) Penz. and Sacc. is one of the most destructive disease of pomegranate (Punica granatum) inflicting considerable quantitative and qualitative losses.

Mostly the disease occurred on leaves and fruits but causes more damages to fruit of pomegranate. Considering the economic importance of the fruit crop as well as disease, present investigation was undertaken for evaluation of systemic, non-systemic and combi fungicides in vitro against $C$. gloeosporoides. In vitro study was conducted in the laboratory of Department of Plant Pathology, College of Agriculture, Latur.

\section{Materials and Methods}

The efficacy of seven systemic, three nonsystemic and four combi fungicides were tested against C. Gloeosporoides for radial growth inhibition on thepotato dextrose agar medium using poisoned food technique under in vitro condition.

The systemic fungicides were tried at 1000 ppm concentration, whereas, non-systemic and combi fungicides were tried at $2000 \mathrm{ppm}$ concentrations. The list of fungicides used along with their chemical and trade names are given in Table 3.

The poisoned food technique (Nene and Thapliyal, 1993) was followed to evaluate the efficacy of systemic, non-systemic and combi fungicides in inhibiting the mycelial growth of C. gloeosporoides. The fungus was grown on PDA medium for 12 days prior to setting up the experiment. The PDA medium was prepared and melted. The fungicidal suspension was added to the melted mediumto obtain the required concentrations on commercial formulation basis of the fungicide. Twenty $\mathrm{ml}$ of fungicides poisoned medium was poured in each sterilized Petriplates. Suitable check was maintained without addition of fungicide. Mycelial disc of $5 \mathrm{~mm}$ was taken from the periphery of 12 days old colony was placed in the centre of Petriplates and incubated at $27 \pm 1^{0} \mathrm{C}$ for 12 days andthree replications were maintained for each treatment.

The diameter of the colony was measured in two directions and average was recorded. Per cent inhibition mycelial growth of the fungus was calculated by usingthe formula by Vincent (1927):

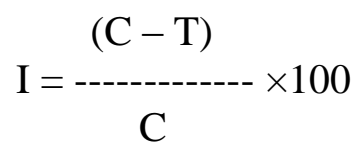

Where,

$\mathrm{I}=$ Per cent inhibition $(\mathrm{mm})$

$\mathrm{C}=$ Radial growth in $(\mathrm{mm})$ control

$\mathrm{T}=$ Radial growth $(\mathrm{mm})$ in treatment.

\section{Results and Discussion}

The results obtained from the present investigation as well as relevant discussion have been summarized under following heads:

\section{Systemic, non-systemic and combi fungicides against $C$. gloeosporoides}

All of the seven systemic fungicides and seven non-systemic and combi fungicides evaluated in vitro were found fungitoxic to Colletotrichum gloeosporoides causing major fungal fruit rot in pomegranate which numerically and significantly influenced mycelial growth and its corresponding inhibition, over untreated control (Table 1 and Plate 1; Table 2 and Plate 2). 
In vitro evaluation of systemic, non-systemic and combi fungicides against $C$. gloeosporoides

Screening of fungicides was done against $C$. gloeosporoides under laboratory condition by following poisoned food technique as described in "Materials and Methods".

Seven systemic and seven non-systemic (three) and combi (four) fungicides were evaluated against $C$. gloeosporoides in laboratory at $1000 \mathrm{ppm}$ (Systemic fungicides) and $2000 \mathrm{ppm}$ (three Non-systemic and four combi fungicides) concentrations by poisoned food technique.

Data with respect to inhibition of mycelial growth of $C$. gloeosporoides at $1000 \mathrm{ppm}$ concentrations of seven systemic fungicides were recorded and presented in Table 1.

Data from Table 1 revealed that, the efficacy of different systemic fungicides at $1000 \mathrm{ppm}$ concentrations and their interaction on per cent inhibition of mycelial growth of $C$. gloeosporoides differed significantly.

Maximum per cent inhibition (87.23\%) of $C$. gloeosporoides was recorded in systemic fungicides Carbendazim $50 \mathrm{WP}$ which was significantly superior over all other systemic fungicides followed by Difenconazole $25 \mathrm{EC}$ (85.74\%), Benomyl 50 WP (85.66\%), Tebuconazole 25.9 EC (83.08\%), Thiophanate methyl 70 WP (83.03\%), Hexaconazole 5 EC $(81.81 \%)$ and Propiconazole 25 EC (74.66\%).

Least per cent inhibition was noticed in Propiconazole 25 EC (74.66\%).

Data with respect to inhibition of mycelial growth of C. gloeosporoides at $2000 \mathrm{ppm}$ concentrations of seven non-systemic and combi fungicides were recorded and per cent inhibition were recorded and presented in
Table 2. It was observed that, fungicides, concentrations and their interaction differed significantly with respect to inhibition of the mycelial growth of C. gloeosporoides. Among seven non-systemic and combi fungicides, maximum per cent inhibition of growth of $C$. gloeosporoides was observed in Carboxin 37.5 + Thirum 37.5 75 WP recorded highest per cent inhibition of mycelial growth $(95.62 \%)$ of fungus $C$. gloeosporoides which was significantly superior over other non-systemic and combi fungicides followed by Carbendazim 12\% + Mancozeb 63\% 75 WP (94.00\%), Propineb 70 WP (51.48\%), Chlorothalonil 75 WP (48.14\%), Mancozeb 75 WP (42.77\%) Metalaxyl 8\% + Mancozeb 64\% 72 WP (33.07\%) and Cymoxanil 8\% + Mancozeb $64 \quad \% \quad 72$ WP (19.73\%).The leastinhibition of fungus was recorded in combi fungicides Cymoxanil 8\% + Mancozeb $64 \% 72$ WP (19.73\%).

Thus, all of the systemic, non-systemic and combi fungicides tested were found fungistatic against C. gloeosporoides and numerically inhibited its mycelia growth, over untreated control.

However, the systemic fungicides found most effective in their order of merit were Carbendazim 50 WP (87.23\%), Difenconazole 25 EC (85.74\%), Benomyl 50 WP (85.66\%), Tebuconazole 25.9 EC $(83.08 \%)$, Thiophanate methyl 70 WP (83.03\%), Hexaconazole 5 EC (81.81\%) and Propiconazole 25 EC (74.66\%).

Non- systemic and combi fungicides found most effective in their order of merit were Carboxin 37.5 + Thiram 37.5 75 WP (95.62\%), followed by Carbendazim $12 \%+$ Mancozeb 63\% 75 WP (94.00\%), Propineb 70 WP (51.48\%), Chlorothalonil 75 WP (48.14\%), Mancozeb 75 WP (42.77\%) Metalaxyl 8\% + Mancozeb 64\% 72 WP (33.07\%) and Cymoxanil 8\% + Mancozeb 64 $\% 72$ WP (19.73\%). 
Plate.1 In vitro efficacy of systemic fungicides @ 1000 ppm against $C$. gloeosporoides causing fruit rot in Pomegranate. Plate.2 In vitro efficacy of non-systemic and combi fungicides @ 2000 ppm against $C$. gloeosporoides causing fruit rot in Pomegranate

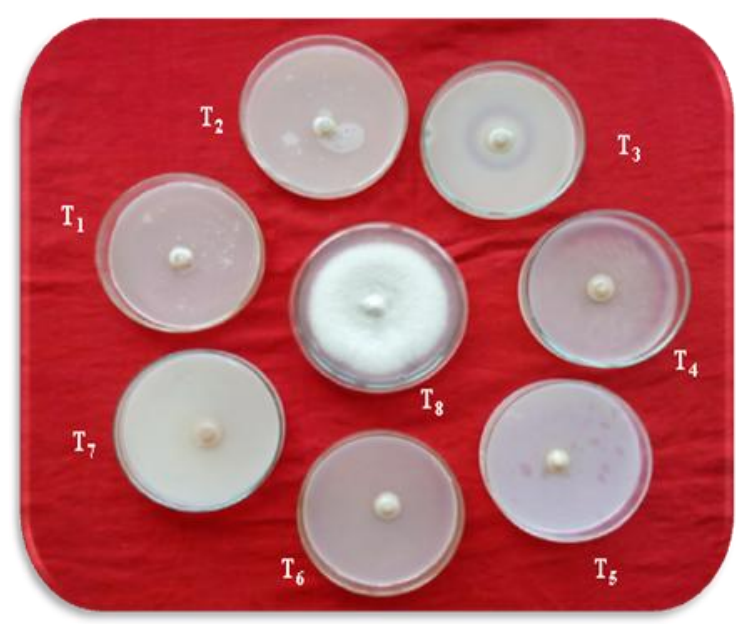

Plate.1

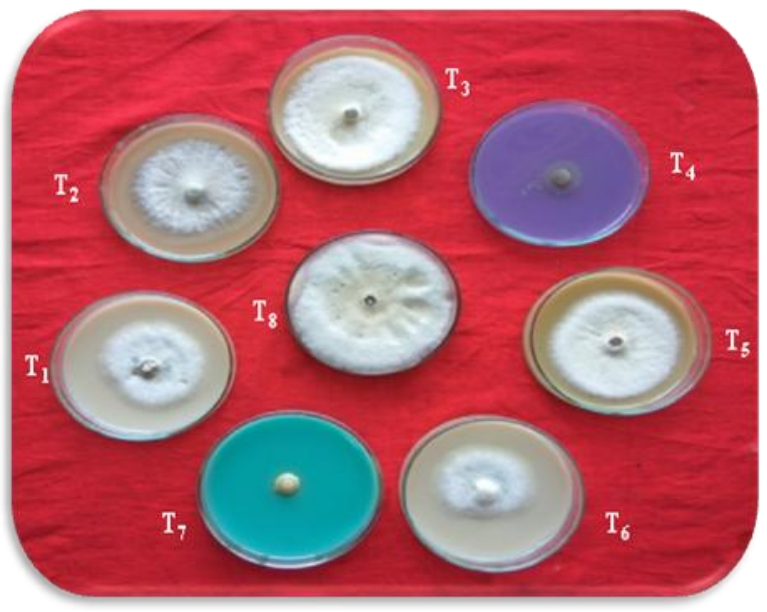

Plate. 2

Table.1 In vitro efficacy of systemic fungicides @ $1000 \mathrm{ppm}$ against $A$. alternata, causing fruit rot in pomegranate

\begin{tabular}{|c|l|c|c|}
\hline Tr. No. & Treatments & Col. Dia. $(\mathbf{m m})^{*}$ & \% Inhibition* \\
\hline $\mathbf{T}_{\mathbf{1}}$ & Carbendazim 50 WP & 10.93 & 87.23 \\
\hline $\mathbf{T}_{\mathbf{2}}$ & Propiconazole 25 EC & 22.50 & 74.66 \\
\hline $\mathbf{T}_{\mathbf{3}}$ & Hexaconazole 5 EC & 16.00 & 81.81 \\
\hline $\mathbf{T}_{\mathbf{4}}$ & Difenconazole 25 EC & 12.50 & 85.74 \\
\hline $\mathbf{T}_{\mathbf{5}}$ & Tebuconazole 25.9 EC & 14.73 & 83.08 \\
\hline $\mathbf{T}_{\mathbf{6}}$ & Benomyl 50 WP & 12.60 & 85.66 \\
\hline $\mathbf{T}_{\mathbf{7}}$ & Thiophanate methyl 70 WP & 14.80 & 83.03 \\
\hline $\mathbf{T}_{\mathbf{8}}$ & Control (untreated) & 90.00 & 00.00 \\
\hline & S.E. \pm & $\mathbf{0 . 3 9}$ & $\mathbf{0 . 6 0}$ \\
\hline & C.D. at 1\% & $\mathbf{1 . 1 3}$ & $\mathbf{1 . 7 6}$ \\
\hline
\end{tabular}

*: Mean of three replications, Col.: Colony, Dia.: Diameter, Figures in parentheses are arcsine transformed values

Table.2 In vitro efficacy of non-systemic and combi fungicides @ 2000 ppm against A. alternata, causing fruit rot in pomegranate

\begin{tabular}{|c|l|c|c|}
\hline Tr. No. & \multicolumn{1}{|c|}{ Treatments } & Col. Dia. $(\mathbf{m m})^{*}$ & \% Inhibition* \\
\hline $\mathbf{T}_{\mathbf{1}}$ & Chlorothalonil 75WP & 47.43 & 48.14 \\
\hline $\mathbf{T}_{\mathbf{2}}$ & Mancozeb 75WP & 51.60 & 42.77 \\
\hline $\mathbf{T}_{\mathbf{3}}$ & Cymoxanil 8 \% + Mancozeb 64\%(72WP) & 72.53 & 19.73 \\
\hline $\mathbf{T}_{\mathbf{4}}$ & Carboxin 37.5 +Thiram 37.5 (75WP) & 4.40 & 95.62 \\
\hline $\mathbf{T}_{\mathbf{5}}$ & Metalaxyl 8\% +Mancozeb 64\% (72 WP) & 62.00 & 33.07 \\
\hline $\mathbf{T}_{\mathbf{6}}$ & Propineb 70 WP & 44.51 & 51.48 \\
\hline $\mathbf{T}_{\mathbf{7}}$ & Carbendazim 12\% +Mancozeb 63\% (75 WP) & 6.53 & 94.00 \\
\hline $\mathbf{T}_{\mathbf{8}}$ & Control (untreated) & 90.00 & 00.00 \\
\hline & S.E. \pm & $\mathbf{0 . 4 3}$ & $\mathbf{0 . 4 8}$ \\
\hline & C.D. at 1\% & $\mathbf{1 . 2 7}$ & $\mathbf{1 . 4 2}$ \\
\hline
\end{tabular}

*: Mean of three replications, Col.: Colony, Dia.: Diameter, Figures in parentheses are arcsine transformed values 
Table.3 The list of fungicides used along with their chemical and trade names

\begin{tabular}{|c|c|c|c|}
\hline Sr. No. & Common name & $\begin{array}{l}\text { Trade name } \\
\text { (A. I.*) }\end{array}$ & Chemical name \\
\hline \multicolumn{4}{|c|}{ Systemic fungicides } \\
\hline 1. & Carbendazim & Bavistin50 WP & Methyl 1H-Benzimidazole-yl carbamate \\
\hline 2. & Propiconazole & Tilt 25 EC & $\begin{array}{l}\text { 1-(-2-(2,4-dichloropheny)-4-propyl-1,3- } \\
\text { dioxolanyl methyl)- 1H-1-4 triazole }\end{array}$ \\
\hline 3. & Hexaconazole & Contaf5 EC & $\begin{array}{l}\text { RS)-2-(2,6-dichlorophenyl-4prophyl,3-dioxolany } \\
\text { 2-yl)methyl)-1H-1,2,6- }\end{array}$ \\
\hline 4. & Difenconazole & Score25 EC & $\begin{array}{l}\text { Cis-trans-3-chloro-4-(4-methyl-2-(1H-1,2,4- } \\
\text { trizol-1-yl methyl)1,3-dioxolan-2-yl) phenyl } 4 \text { - } \\
\text { chlorophenyl ether }\end{array}$ \\
\hline 5. & Tebuconazole & Folicur25.9 EC & $\begin{array}{l}\text { (RS)-1-(4-Chlorophenyl)-4, } \\
\text { (1H,1,2,4-triazol-1-yl-methyl) pentan-3-01 }\end{array}$ \\
\hline 6. & Benlate & Benomyl50WP & $\begin{array}{l}\text { Methyl1-(butyl carbamamoyl)- } \\
\text { 2Benzimidazolecarbaonate }\end{array}$ \\
\hline 7. & Thiophanate methyl & $\begin{array}{l}\text { Topsin- } \\
\text { M/Roko70WP }\end{array}$ & $\begin{array}{l}\text { 1-(biphenyl-4-yloxy)-3-3dimethy-1,2,4 trilzol-1- } \\
\text { yl) }\end{array}$ \\
\hline \multicolumn{4}{|c|}{ Non-systemic fungicides } \\
\hline 8. & Propineb & Antracol70WP & Zinc propylene-bis-dithiocarbamate \\
\hline 9. & Chlorothalonil & Kavach75 WP & Tetrachloroisophthalonitrile \\
\hline 10. & Mancozeb & $\begin{array}{l}\text { Dithane M-4575 } \\
\text { WP }\end{array}$ & $\begin{array}{l}\text { Manganese ethylene bis (dithhiocarbamate) } \\
\text { polymeric complex with zinc }\end{array}$ \\
\hline \multicolumn{4}{|c|}{ Combi- fungicides } \\
\hline 11. & $\begin{array}{l}\text { Cymoxanil 8\% + } \\
\text { Mancozeb } 64 \%\end{array}$ & Curzet72 WP & $\begin{array}{l}\text { 1-(2-cyano-2 methoxyiminoacetyl)-3-acetamide } \\
\text { + manganese ethylene bisdithhiocarbamate }\end{array}$ \\
\hline 12. & $\begin{array}{l}\text { Carbendazim } 12 \%+ \\
\text { Mancozeb } 63 \%\end{array}$ & SAAF75 WP & $\begin{array}{l}\text { Methyl 1-1-2 benzimidazole carbonate }+ \text { zinc ion } \\
\text { and manganese ethylene bis } \\
\text { dithiocarbamate. }\end{array}$ \\
\hline 13. & $\begin{array}{l}\text { Carboxin } 37.5 \%+ \\
\text { Thiram } 37.5 \%\end{array}$ & $\begin{array}{l}\text { Vitavax Power } \\
75 \text { WP }\end{array}$ & $\begin{array}{l}\text { 3-(3-5-dichlorophenyl)-N-(1-methylethyl)-2-4- } \\
\text { dioxo-1-lemadazolidine carboxamide } \\
\text { thetramethylthirum disulphide }\end{array}$ \\
\hline 14. & $\begin{array}{l}\text { Metalaxyl } 8 \%+ \\
\text { Mancozeb } 64 \%\end{array}$ & $\begin{array}{l}\text { Ridomil MZ } 72 \\
\text { WP }\end{array}$ & $\begin{array}{l}{[(1,2 \text {-ethanediybis }[\text { carbamadithiot })](2-)]} \\
\text { manganese mixture with zinc+methyl N-(2,6- } \\
\text { dimethylphenyl)-N-(methoxyacetyl)-Dl- } \\
\text { alaninate }\end{array}$ \\
\hline
\end{tabular}

These results of the present study concedes with the reports of earlier workers who reported effectiveness of the systemic, nonsystemic and combi fungicides such as Prashanth et al., (2008) reported that among four systemic fungicides maximum \%inhibition of growth of $C$. gloeosporioides was observed in Difenconazole $(90.78 \%)$ and Propiconazole (90.78\%), Gud and Raut (2008) reported that Thiophenate-methyl and Propiconazole were most effective against $C$. gloeosporioides followed by Hexaconazole and Carbendazim. Patel (2009) and Pandey et al., (2012) studied that among the tested 
fungicides Tricyclazoles were found to be superior for controlling C. gloeosporioides causes anthracnose of mango.

At higher concentration (2000 ppm) most of the fungicides viz. Hexaconazole, Propiconazole, Penconazole, Tebuconazole, Carbendazim, Azoxystrobin, Difenoconazole, Thifluzamide and Trifluoxystrobin inhibited maximum mycelial growth but decreased with reduced concentration $(500 \mathrm{ppm}$ and 1000 $\mathrm{ppm})$. These results are in agreement with that of Sudhakar (2000); Prashanth (2007); Patel (2009); Devamma et al., (2012) reported that among all the six fungicides evaluated against C. gloeosporioides the cause of mango anthracnose, the systemic fungicide Thiophanate-methyl $(100 \%)$ and the nonsystemic fungicide Mancozeb (100\%) proved to be effective in inhibiting the mycelial growth of the highly virulent pathogen at 50 ppm and $500 \mathrm{ppm}$ concentrations, respectively. Similarly, Pandey et al., (2012) studied the effect of different fungicides on the control of $C$. gloeosporioides causes anthracnose of mango. Among the tested fungicides Tricyclazoles were found to be superior for controlling the incidence of pathogen and Saju et al., (2012) reported the effectiveness of different fungicides against C. gloeosporioides infecting large cardamom, the in vitro tests showed that, the pathogen was highly sensitive to Copper oxychloride $50 \mathrm{WP}(0.3 \%)$ followed by Mancozeb $75 \mathrm{WP}$ $(0.3 \%)$ and combined formulation of Carbendazim + Mancozeb $(12+63)$ WP $(0.3$ $\%)$. Thus the results of earlier workers are also inline with the results obtained in the present investigation.

Thus from the present investigations, it was evident that, among the different systemic fungicides evaluated Carbendazim, Difenconazole, Benomyl, Tebuconazole, Thiophanate methyl, were most effective as well as non-systemic and combi fungicides
Carboxin + Thiram, Carbendazim + Mancozeb, Metalaxyl + Mancozeb, Propineb, Chlorothalonil, Mancozeb were found highly efficient in the management of Colletotrichum gloeosporioides causing major fungal fruit rot disease in pomegranate.

\section{References}

Anonymous (2013). Area under pomegranate cultivation in India and Maharashtra. National Horticultural Board, 62.

Butler, E. J. (1918). Fungi and Diseases in plants. Thacker Spink and Co. Kolkata, India.

Devamma, M.N., Rajkumari, J.P. and Devi, P.S. (2012). Fungicide compatible potential biocontrol agents against Colletotrichum gloeosporioides Penz. causing mango anthracnose. Current Biotica, 5(4): 454-464

Gud, M.A. and Raut, S.P. (2008). Control of mango anthrac-nose and stem end rot fungi by fungicides and bio-agents. $J$. Maharashtra Agric. Uni., 33(1): 120122

Nene, Y. L. and Thapliyal, P.N. (1993). Evaluation of fungicides. In: Fungicides in Plant disease Control ( $3^{\text {rd }}$ ed.) Oxford IBH publishing co., New Delhi: 331.

Pandey, A., Yadava, L.P., Manoharan, M., Chauhan, U.K. and Pandey, B.K. (2012). Effectiveness of cultural parameters on the growth and sporulation of Colletotrichum gloeosporioides causing anthracnose disease of mango (Mangifera indica L.). OJBS, 12(4): 123-133

Patel, D.S. (2009). Chemical management of fruit spot of pomegranate caused by Colletotrichum gloeosporioides Penz. and Sacc. Indian Phytopathol., 62(2): 252-253

Penz. (1884). Fungi Agrum, 2: 6.

Prashanth, A. (2007). Investigation on anthracnose

(Colletotrichum 
gloeosporioides (Penz.) Penz. And Sacc.) of pomegranate (Punica granatum L.). M.Sc. (Agri.) Thesis, Uni. Agric. Sci., Dharwad (India).

Prashanth, A., Arun, R.S., Naik, M.K., Patil, M.B. and Ra-jesh, S.P. (2008). Evaluation of fungicides, bioagents, and botanicals against pomegranate anthracnose. Indian J. Plant Protec., 36(2): 283-287

Saju, K.A., Deka, T.N., Gupta, U., Biswas, A.K. and Sudhar-shan, M.R. (2012). In vitro evaluation of biocontrol agents, botanicals and fungicides against Colletotrichum gloeosporioides infecting large cardamom. Pl. Dis. Res., 27(1): 49-53

Sudhakar, (2000). Biology and management of Stylosanthes anthracnose caused Colletotrichum gloeosporioides (Penz). Penz. and Sacc. M.Sc. (Agri.) Thesis, Uni. Agric. Sci., Dharwad (India), pp. 34-35

Vincent, J. M. (1927). Distortion of fungal hyphae in the presence of certain inhibitors, Nat.: 159-180.

\section{How to cite this article:}

Burgute, K.A. and Magar, S.J. 2019. In vitro Evaluation of Systemic, Non-Systemic and Combi Fungicides against Colletotrichum gloeosporoides Causing Fungal Fruit Rot in Pomegranate. Int.J.Curr.Microbiol.App.Sci. 8(08): 450-456. doi: https://doi.org/10.20546/ijcmas.2019.808.051 